\title{
Early Detection of Developmental Disorders Screening for Early Childhood
}

\author{
Dewi Retno Suminar \\ Faculty of Psychology, Airlangga University, Surabaya, Indonesia \\ Corresponding e-mail: dewi.suminar@psikologi.unair.ac.id
}

\begin{abstract}
Screening for early childhood is very important, because in the life span perspective childhood will determine the next period. Early childhood teachers often feel confused when seeing their student experiencing developmental delays, but find it difficult to do early detection, due to some of the same behavioral characteristics that are shared by several developmental disorders. Gullo (2005) which states that the development of the screening area can be viewed from three areas: (1). Area of visual motor skills and adaptation, (2). Areas of language and thinking, and (3). Gross motor area. Thus, this measure will see aspects of sensory development, relationships, emotions, cognition and physical. The constructed measuring tool for early detection developmental disorders (ED3) has been through the pilot phase of study and field testing. In the pilot study, the measuring tools was specifically used to detect the tendency of some developmental disorders, such as autism, mental retardation, ADD/ADHD, and learning difficulties. Furthermore, in the process of professional judgment, focus group discussion was conducted to generate this early detection developmental disorders (ED3) screening tool. In the process of field testing, 40 people from field personnel (bunda PAUD) were trained to use the measuring instruments. Field test was conducted on 389 children, 204 boys and 185 girls who are considered problematic. The range of subject's age was 17-74 months with an average age of 46 months. Field test results showed that this measuring tool can be adminitered by the teacher or adult who is close to early children. This instrument is equipped with the manual tools, as well as supporting tools such toys, whistles, scissors, crayons, beads and strings. This screening tool can be used along with other tools and is useful for early detection.
\end{abstract}

Keywords: screening, early detection, early childhood

\section{INTRODUCTION}

Developmental screening in early childhood is defined as "a procedure of brief assessment designed to identify children who, due to the risk of possible learning difficulties or ... (special needs), need to follow the diagnostic assessment at a level deeper" (Gullo 2005: 44).

In general, developmental screening is not only beneficial to determine whether a child's development is in accordance with his age, but also provides a basis for planning programs and early childhood education service model, which according to the characteristics of children, thus supports early child development optimization. Meisels (1987, in Gullo, 2005) explains that there are two main objectives of developmental screening. The first is to identify children who may need special education services. The second is to identify children who would benefit from a special education draft in regular classes. In the end, the function of screening test is to measure the child's learning potential.

Developmental screening test is an assessment instrument based on the norms by comparing scores of a child with other children at the same chronological age. Although each test emphasizes on different aspects of child development, there are three main areas that are generally present in the development screening tests. The first area is related to visual motor skills and adaptation. This includes the movement of fine motor skills, hand-eye coordination, the ability to remember a sequence of visual stimuli, to choose the shape with a twodimensional representation of the object and 
reproducing three-dimensional model. The second area, is skills related to language or communication and thinking. The tasks in this area include the comprehension and expression of language, reasoning, numeracy and ability to remember the sequence of auditory stimulus. The third area includes gross motor skills and body awareness. This includes balance, coordination of large muscle movements, and awareness of body position. Screening can also be used at an early stage identification of special needs, as an indication of whether further assessment is required for diagnostic needs (Gullo, 2005).

The research objective to be achieved is the availability of developmental screening tool to detect early developmental disorders that have been tested empirically. Meanwhile, the benefits to be achieved through this research are (a). Providing information about child development, (b). Providing information on whether children in deviant category, (c). Notifying categories of developmental disorders that occur in children, (d). Providing knowledge and guidance for parents who have toddlers to better understand the early aspects of the irregularities that occur in children, (e). Making it easier for caregivers and early childhood educators to classify aspects of developmental disorders in children.

\section{METHOD}

\subsection{Stage of Research}

This research aims to construct a measuring instrument in the form of early detection of developmental disorders (ED3). Azwar (2012) state that construction of measuring instruments, particularly in the form of scale, will take several steps: (1). Identifying the objective of measuring instruments, (2). Domain restriction of measurement, (3). Operationalization of aspects, (4). writing items, (5). The trial of language, (6). Field trial, (7), estimation of reliability and (8). Constructing validation. The final form of the measuring instrument is a test booklet, user's manual, technical manual and norm

Stages of the research (1). Preparation of the screening tools through literature study stage and focus group discussion that has discussed the characteristics of developmental disorders. The included developmental disorders are the basis of mental retardation, ADD/ADHD, autism and learning difficulties in general. Further, development of the instruments was through an FGD by 36 judges, in which the behavioral traits were grouped because some behavioral traits may belong to more than one developmental disorder. The last step in the drafting stage is to develop a screening tool into a format based on each aspect, (2). The process of screening tool testing was done through several stages, making the tools used as a tool that enables easy measurement, training of 40 field personnel and performing field tests on 389 children,

The model used is concentrated on the diagnostic model to be tested in the field. The model of measuring instrument is made based on the characteristics of normal holistic children where, according to Berns (2010), children can interact with their environment which reflects cognitive, physical, social and emotional development. Thus, the developmental aspects invloved are sensory, physical, cognitive, emotional development and relationships with others.

\subsection{Measuring instrument}

Developmental screening is a holistic concept of the developmental aspects of children's views, based on aspects of cognitive development, physical, social and emotional, which according to the literature review, refer to the developmental aspects of sensory, physical, cognitive, emotional and relational. The designed measuring instrument is a measure that has gone through testing of professional judgment, calculation of Content Validity Ratio (CVR) and the Content Validity Index (CVI). The measuring instrument is called a screening tool of early detection of developmental disorders (ED3)

\subsection{Data collection technique}

The methods of data collection are divided into two stages. The first one is the preparation of measuring instruments (pilot study). The latter is field testing of the measuring instrument that has been constructed. The data collection started with training of field workers to understand the usage screening tool of early detection of developmental disorders (ED3). These field personnel used the measuring instrument ED3 for use in early childhood

\subsection{Data analysis}

Analysis of the research was carried out by making a comparison, tabulation, crosscheck the result of several stages from the result of FGD to the professional judgment and then describing the data 
in the table. Thus, more directed analysis of data description

\section{RESULT}

\subsection{Results of Measurement Construction}

The aspects of development included in detecting developmental disorders are sensory, cognitive, physical, emotional and relational. The study was conducted after reviewing the theory of Gullo (2005) which states that the development of the screening area can be viewed from three areas: (1). Area of visual motor skills and adaptation, (2). Areas of language and thinking, and (3). Gross motor area. Table 1 below shows the compilation of developmental aspects based on the FGD.

Table 1. Compilation of screening areas and aspects of development

\begin{tabular}{|c|c|}
\hline SCREENING AREA & $\begin{array}{c}\text { ASPECTS OF } \\
\text { DEVELOPMENT }\end{array}$ \\
\hline $\begin{array}{l}\text { Visual motor skills \& } \\
\text { adaptive } \\
\text { Language and thinking } \\
\text { Gross motor skills }\end{array}$ & $\begin{array}{l}\text { Sensory, relationships, } \\
\text { emotions, } \\
\text { Cognition } \\
\text { Physical }\end{array}$ \\
\hline
\end{tabular}

Table 1 shows the relationship between screening areas with developmental aspects. Area visual motor skills and adaptation of children is a reflection of the developmental aspects of sensory, relationships and emotions. Similar to the screening area of language and thought is an aspect of cognitive development. Gross motor skills are the description of aspects of physical development. Based on this process, then eventually the reference in analyzing the development is the sensory, relationships, emotions, cognition and physical aspects.

In fact, the results of field measuring tools need to be made in the form of a book in order to facilitate field workers in collecting the data. After the process of professional judgment, the measuring instrument contains some items on each aspect of development. Number of items in each developmental aspect is 13 items for the sensory aspects, 13 items for physical aspects, 11 items for aspects of cognition, 16 items for emotional aspects, and 16 items of aspects of the relationship. Before the field testing, measuring tools have been improved and additional tools for some points the items are contained in the measuring instrument.
Based on the trials, some additional tools are necessary if the result of current screening is still not convincing. These additional tools are used when using the main measuring tools is dubious and further assessment is necessary. However, if it is not, he tools and its functions can be seen in table 2 .

Table 2. Tools and functions

\begin{tabular}{|c|c|}
\hline TOOLS & FUNCTION \\
\hline Feathers & $\begin{array}{l}\text { Sensitivity stimulation at } \\
\text { hand }\end{array}$ \\
\hline Whistle & Sensitivity to loud noises. \\
\hline $\begin{array}{l}\text { Stationery (paper \& } \\
\text { pencil) }\end{array}$ & Detecting how to write \\
\hline Beads with string & $\begin{array}{l}\text { Detecting eye-hand } \\
\text { coordination }\end{array}$ \\
\hline $\begin{array}{l}\text { Pictorial paper, colored } \\
\text { pencil, scissor, paper \& } \\
\text { glue }\end{array}$ & $\begin{array}{l}\text { Detecting fine motor } \\
\text { skills, especially dyeing, } \\
\text { cutting and sticking }\end{array}$ \\
\hline
\end{tabular}

\subsection{Field Test Results}

The field testing of the measuring instruments was conducted by field workers who had received training in using measuring instruments. The field workers were 40 early childhood educator (Bunda PAUD). The reason for involving Bunda PAUD in the datab, is because they are the closest person to the early children, aside from the child's parents.

The research subjects in the field test of measuring instruments Early Detection Developmental Disorders (ED3) were 389 children aged between 17 months to 74 months. The average age of the study subjects was 46 months. The age of subjects is regarded in months, instead of years, because the measure in early childhood will give better results if done using months due to the rapid development in early childhood. The overview of subjects' age can be seen in Table 3 .

Table 3. Overview of the subject age

\begin{tabular}{rrrlr}
\hline & N & Mini & Max & Mean \\
\hline BULAN & $\mathbf{3 8 9}$ & $\mathbf{1 7 . 0 0}$ & $\mathbf{7 4 . 0 0}$ & $\mathbf{4 6 . 3 5 7 3}$
\end{tabular}

Distribution of research subjects by their sex is as follows. Male subjects were more than female. Of the 389 subjects, there were 204 boys and 185 girls. This shows that the boys have a tendency to experience four developmental disorders such as Autism, mental retardation, ADD / ADHD and 
learning difficulties than girls (Bannet, 2006). The prevalence of the disorder, especially autism and ADD / ADHD, are higher in in boys than in girls.

Table 4. Child status overview of the subject

\begin{tabular}{ccc}
\hline Birth order & Frequency & Percent \\
\hline 1 & 241 & 62.0 \\
2 & 98 & 25.2 \\
3 & 40 & 10.3 \\
4 & 8 & 2.1 \\
5 & 2 & 5 \\
\hline Total & 389 & 0.0 \\
\hline
\end{tabular}

Table 4 shows that the majority of subject with developmental problem was is first children. In psychology, the first child has characteristics of being dependent and weak in making decisions. This is understandable because first children grow under conditions of new parenthood. Protective attitude of parents can influence the child's development (Santrock, 2004)

\subsection{Strengths and Weaknesses Measurement}

In the scientific process, this tool has gone through several stages of study and can be justified. This tool can detect developmental disorders by performing a screening simultaneously from four developmental disorders. The strength of this tool is that it's easy to use and can be administered by parents, caregivers and early childhood educators and does not need the measurement expert, psychologist. Since it hasn't been tested widely to cover the diversity of Indonesian community's, it is necessary to measure to get the norm for children in Indonesia. Development of computer program of this of Early Detection of Developmental Disorders (ED3) measuring instruments to assist people in accessing the tool is also necessary

\section{CONCLUSIONS}

The constructed measuring instruments have been through several stages, namely scientific literature review, focus group discussions, professional judgment and manufacture of the measuring tools and the latest format is the construction of the manual of measurement tool for early detection screening for developmental disorders (ED3).The results of field-proven measuring instrument is not hard to do.
Suggestion for future development, it is necessary to make a similar measure based on criteria of other developmental disorders. The assessment for learning disabilities needs to be made more specific to the types of learning difficulties.

\section{REFERENCES}

American Psychological Association. (2010). Publication manual of the Americam Psychological Association ( $\left.6^{\text {th }} e d\right)$. Washington DC: Author.

Atkinson.S \& Tomley, S.(2012). The psychology book. London: Dorling Kondensley Limeted

Azwar,S. (2012). Penyusunan skala psikologi. edisi 2. Yogjakarta: Pustaka Pelajar Offset. ISBN: 979-9289-08-4

Bennett, P. (2006). Abnormal and clinical psychology. An introductory textbook. $2^{\text {nd }}$ Edition New York: McGraw-Hill

Berns, R.M. (2010). Child, family, school, community: socialization \& support. California: Thomson Hingher Education

Billman,J \& Sherman, J. (2003). Observation and Participation in early Childhood settings. a praticum guide. New York: Allyn \& Bacon

Daniels, D.H., Beaumont, L.J. \& Doolin, C.A.(2002) Understanding Childhren: An interview and Observation Guide for Educators. Boston : McGraw-Hill

Dorling Kindersley limited (2012) The Psychology book. London: Penguin group). ISBN: 978-1-4053-9124-5

Graziano, A.M. (2002). Developmental disabilities. An introduction to A Diverse Field. Boston : Allyn and Bacon

Gullo, D.F. (2005). Understanding assessment and evaluation in early childhood education. New York: Teachers College, Columbia University.

Gestwicki,C. (2007). Developmentally Appropriate practice: curriculum and development on Early Education. $3^{\text {nd }}$ Edition. Canada:Thomson Delmar Learning

Hallahan, D.P \& Kauffman, J.M. (2010). Exceptional children. Introduction to special Educatio. $5^{\text {nd }}$ Edition. New Jersey. Prentice Hall Lee, A. Childminder;s Guide to Child Development London: Continuum International Publishing Group.

Lidz, C.S. (2003). Early childhood assesment. New Jersey: John Wiley \& Sons,Inc.

Missouri Autism Guidelines initiative, (2012), autism spectrum dissorder, guide to evidencebased interventions. Consensus Publication 
Putra,N. \& Dwilestari,N. (2012). Penelitian

kualitatif:pendidikan anak usia dini. Jakarta:

PT Raja Grafindo Persada

Santrock, J.W. (2004). Child Development. $10^{\text {th }} \mathrm{ed}$. New York: Mc Graw- Hill.

Wenar,C. (1994). Developmental Psychopathology: From Infancy Through Adolescence. New York : McGraw-Hill, Inc

Wolfgang,C.H.(2004). Child Guidance Through

Play: Teaching Positive Social Behavior (Ages 2- 7). Boston: Pearson Education,Inc. 